IZA DP No. 8804

Dual Labour Markets at Work:

The Impact of Employers' Use of Temporary Agency

Work on Regular Workers' Job Stability

Boris Hirsch

January 2015 


\title{
Dual Labour Markets at Work: The Impact of Employers' Use of Temporary Agency Work on Regular Workers' Job Stability
}

\author{
Boris Hirsch \\ University of Erlangen-Nuremberg \\ and IZA
}

Discussion Paper No. 8804

January 2015

IZA

P.O. Box 7240

53072 Bonn

Germany

Phone: +49-228-3894-0

Fax: +49-228-3894-180

E-mail: iza@iza.org

Any opinions expressed here are those of the author(s) and not those of IZA. Research published in this series may include views on policy, but the institute itself takes no institutional policy positions. The IZA research network is committed to the IZA Guiding Principles of Research Integrity.

The Institute for the Study of Labor (IZA) in Bonn is a local and virtual international research center and a place of communication between science, politics and business. IZA is an independent nonprofit organization supported by Deutsche Post Foundation. The center is associated with the University of Bonn and offers a stimulating research environment through its international network, workshops and conferences, data service, project support, research visits and doctoral program. IZA engages in (i) original and internationally competitive research in all fields of labor economics, (ii) development of policy concepts, and (iii) dissemination of research results and concepts to the interested public.

IZA Discussion Papers often represent preliminary work and are circulated to encourage discussion. Citation of such a paper should account for its provisional character. A revised version may be available directly from the author. 


\section{ABSTRACT}

\section{Dual Labour Markets at Work: The Impact of Employers' Use of Temporary Agency Work on Regular Workers' Job Stability*}

Fitting duration models on an inflow sample of jobs in Germany starting in 2002-2010, this paper investigates the impact of employers' use of temporary agency work on regular workers' job stability. In line with dual labour market theory, I find that non-temp jobs are significantly more stable if employers utilise temps. The rise in job stability stems mainly from reduced transitions into non-employment suggesting that non-temp workers are safeguarded against involuntary job losses. My findings are robust to controlling for unobserved permanent employer characteristics and changes in the observational window that includes the labour market disruption of the Great Recession.

JEL Classification: J63, J41, J21

Keywords: temporary agency work, job stability, dual labour markets

Corresponding author:

Boris Hirsch

University of Erlangen-Nuremberg

Chair of Labour and Regional Economics

Lange Gasse 20

90403 Nuremberg

Germany

E-mail: boris.hirsch@fau.de

I would like to thank Jürgen Deinhard, Elke Jahn, Steffen Müller, Michael Oberfichtner, Claus Schnabel, and Thomas Zwick for very useful suggestions. I further thank the team of the Research Data Centre at the Institute for Employment Research for their invaluable help with the data. 


\section{Introduction}

Following the Great Recession, there has been an upsurge of interest in the role of labour market institutions on aggregate labour market performance. A special focus has been laid on so-called two-tier reforms put in place in many European countries that have liberalised a segment of the labour market while maintaining strong regulations for the majority of workers working outside this segment (Boeri, 2011). Due to its significant deregulation in several countries and its rapid worldwide growth, temporary agency work (TAW) is at the heart of this rise in labour markets' dualism.

In a labour market characterised by strong dismissal protection for permanent workers, TAW and other forms of flexible labour constitute a 'second tier' that allows employers to achieve numerical employment flexibility. In particular, TAW provides employers with a means to handle variability in demand and to buffer regular workers during economic downturns. It thus enables them to sustain internal labour markets and investments in their permanent workers' firm-specific human capital. Admitting employment flexibility in the 'second tier' of the labour market is, then, expected to increase the job stability in the 'first tier' of the labour market, at the expense of workers in the 'second tier' whose employment gets more volatile (Saint-Paul, 1996).

In line with these theoretical expectations, a recent macro-econometric study by Jahn and Weber $(2014 a)$ documents that the marked increase in TAW in Germany since the late 1990s has led to a significant fall in the aggregate employment volatility outside the TAW sector. Up to now, however, there exists no direct empirical evidence on the impact of employers' use of TAW on their regular workers' job stability which could shed light on whether resorting to peripheral workers indeed stabilises core workers' jobs as dual labour market theory suggests. To close this gap, this paper looks inside plants and investigates whether non-TAW jobs are more stable in plants making use of TAW. I address this research question using rich linked employer-employee data for Germany, one of the world's biggest markets for TAW, that comprise the years 2002-2010.

Like in most countries worldwide, the German temporary work industry has grown considerably in the last years. The number of employed full-time equivalent workers has 
roughly quadrupled since 1998 and doubled since 2004. In 2010 (i.e. at the end of my period of observation), temporary work agencies employed 793,000 full-time equivalent workers which amounted to about 2.0 per cent of the total active working population of Germany (CIETT, 2012). This number is above the European average of 1.6 per cent. For comparison, the share of temporary agency workers in the total active working population in 2010 was 3.0 per cent in the UK, 2.5 per cent in the Netherlands, 2.0 per cent in France, 1.5 per cent in Japan, and 1.8 per cent in the US.

Remarkably, the growth in TAW in Germany appeared both at the extensive and at the intensive margin, with a rise in the number of plants resorting to TAW and, at the same time, a rise in the number of temps assigned to extant user plants (Hirsch and Mueller, 2012). Although there had been a substantial fall in the number of temps in 2009 as Germany had been hit by the Great Recession, the TAW industry has fully recovered thereafter. Strikingly, around 70 per cent of the total loss in employment (covered by social security) in 2009 was borne by the TAW sector, while 35 per cent of the substantial employment gain in the 2010 recovery appeared in this sector (Federal Employment Agency, 2012). This highlights the role of TAW as an instrument for employers to meet flexibility requirements and to buffer their regular workers during downturns.

One of the main reasons for the rapid growth in TAW in Germany is seen in the massive relaxation of legal hindrances to TAW use. In Germany, as in most European countries, TAW was heavily regulated in the past, but has undergone a widespread deregulation in recent years. When legalising TAW in 1972, the Labour Placement Act (Arbeitnehmerüberlassungsgesetz), which is the national law governing TAW in Germany, included strict regulations. This holds in particular with respect to the employment contract between the temp and the agency, which is the temp's employer hiring out the worker to the user plant. Among these regulations, there were a maximum period of assignment, a prohibition of fixed-term contracts, a ban on re-employment as well as a synchronisation ban (requiring the temp's employment contract with the agency to exceed his or her first assignment), and, from 2002 onwards, a principle of equal payment between temps and perms in user plants if assignment durations exceed 12 months (see Antoni and Jahn, 2009). 
Since the 1990s, however, there have been repeated reforms that deregulated TAW substantially. In particular, the latest and most significant reform in 2003 allowed agencies to free themselves from all these regulations by signing sectoral collective agreements defining, among others, collectively agreed sectoral minimum wages for temps covered by the agreement, which almost all of the agencies did (Antoni and Jahn, 2009). As a consequence, TAW has become one of the backbones of the 'second tier' of the German labour market that has seen an increased dualism since the 1990s.

Against this backdrop, my main result will be that non-TAW jobs are significantly more stable in plants resorting to TAW and that job stability peaks once the share of temps in the workforce exceeds 20 per cent. I will further show that this rise in job stability is mainly driven by a fall in the separations to non-employment which arguably mirrors reduced lay-offs of regular workers. The remainder of this paper is organised as follows: Section 2 describes my data and Section 3 my econometric approach. Section 4 presents and discusses the results and Section 5 various checks of robustness. Section 6 concludes.

\section{Data}

In my empirical analysis of the impact of employers' TAW use on the stability of nonTAW jobs, I will fit duration models on German linked employer-employee data. For this purpose, I will make use of the longitudinal model of the LIAB for the years 2002-2010 (for details on the LIAB, see Alda et al., 2005, and Klosterhuber et al., 2013). This data set links the IAB Establishment Panel, a representative annual survey of German plants (not companies), to the administrative data on all those individuals who work for these plants and contribute to the social insurance system.

The administrative data on workers and their jobs are based on the notification procedure for the German health, pension, and unemployment insurances. This procedure requires all employers to report the necessary information on their workers, where misreporting is legally prohibited. Thus, among others, civil servants and self-employed, who do not contribute to the social security system, are not included. In sum, about 80 
per cent of all people employed in Germany are covered by the system. Inter alia, the data include information for every worker on job durations (on a daily basis), periods of registered unemployment, and worker characteristics such as age, education, sex, nationality, and occupation. $]^{1}$

The employer side of my data comes from the IAB Establishment Panel (for details, see Ellguth et al., 2014). Starting in 1993 (1996), the IAB Establishment Panel has surveyed plants from all industries in West (East) Germany that employ at least one worker covered by the social security system at the 30th June of a year. Response rates of units that have been interviewed repeatedly exceed 80 per cent. Questions deal, among other things, with the number of workers, the composition of the workforce, the plant's commitment to collective agreements at sector or plant level, the existence of a works council, the plant's exporting activity, production technology, and industry. From 2002 onwards, the IAB Establishment Panel also includes information on the number of temps working in a plant.

Using these two data sources allows me to build up an inflow sample of jobs starting between 2002 and 2010 including information on plants' use of TAW ${ }^{2}$ Since I need uninterrupted information on all variables of interest for duration analysis to work, in a first step, I construct a panel of plants with continuous participation in the survey and complete information on all relevant variables in either of the periods 2002-2010, 20032010, 2004-2010, or 2005-2010 $3^{3}$ In a second step, I merge all workers aged 18-55 years holding jobs at these plants with jobs starting between 2002 and 2010 and monthly gross earnings of at least $€ 500$. These jobs are non-TAW jobs by construction because temps

$1 \quad$ Note that the information on workers' education is provided by employers on a voluntary basis and therefore contains inconsistent or missing values for 13.4 per cent of all observations. To alleviate this problem, I impute the information on education employing a procedure proposed by Fitzenberger et al. (2006) that allows inconsistent education information to be corrected. After applying this imputation procedure, I have to drop only 0.7 per cent of jobs due to missing or inconsistent information on education.

2 Note that I exclude 84 plants whose reported share of temps in their workforce amounts to 80 per cent or more, with some of them even reporting that they employ more temps than workers. As plants are asked in the survey how many workers they employed at the 30th of June of a year and how many out of these were temps, these high temp shares are likely to reflect misreporting.

3 Building up an inflow sample based on a balanced panel of plants with continuous survey participation in the full period of observation 2002-2010 would not change my insights but markedly reduce the number of plants and jobs in the sample. 
are registered with their temporary work agencies which I exclude from the sample based on their industry classification. Note that the exclusion of workers older than 55 years is to ensure that ending jobs do not reflect (early) retirement of workers. Further, restricting the sample to jobs with monthly wages of at least $€ 500$ is to guarantee that workers do not hold marginal jobs which are also part of the flexible 'second tier' of Germany's labour market (for details on marginal employment in Germany, see, e.g., Freier and Steiner, 2008).

The data allow me to distinguish two labour market states. A job may either end with a transition to employment, which refers to a new job with another employer (i.e. a plant with a different plant identifier), or with a transition to non-employment, which refers to a subsequent period of registered unemployment or no observation in the data at all. 4 The latter either implies that the individual has changed to non-employment without receiving unemployment benefits or that (s)he has become, for instance, a self-employed worker not included in the data set. While the data do not enable me to disaggregate this category of unknown destination, information from other German data sets suggests that the vast majority of workers in this category have indeed moved to non-employment:5

I end up with an inflow sample of 84,027 non-TAW jobs held by 75,540 workers at 2,016 plants (see Table11). Whereas the average job duration amounts to about two and a quarter years, the median job duration is just slightly longer than one and a half years pointing at a right-skewed job duration distribution. Out of the 84,027 jobs in my sample about 65 per cent end during the observational window, with roughly a quarter of these workers immediately moving to another job and three quarters transiting into non-employment. For further descriptive statistics on the sample, consult Appendix Table A.1.

\section{— Table 1 about here -}

$4 \quad$ I neglect separations if the worker is recalled by the same plant within three months. I also ignore periods of non-employment between two jobs up to a week.

5 See, for example, Bartelheimer and Wieck (2005) for a transition matrix between employment and non-employment based on the German Socio-Economic Panel that allows stratification of this category of unknown destination into detailed categories. Note further that my insights do not hinge on lumping together registered unemployment and unknown destination. I arrive at the same conclusions when considering three rather than two different labour market states. 
Turning to plants' TAW use in my sample, I find very similar patterns to those for the overall TAW use in the German economy reported in Section 1. As can be seen from the solid line in Figure 1, in the beginning of the observational window in 2002 the average share of temps among the workforce of all plants in my sample amounted to 1.2 per cent and rose steadily to 2.4 per cent in 2008. In 2009, when the German labour market was hit by the Great Recession, the temp share dropped to 1.3 per cent, and it subsequently recovered to 2.1 per cent in 2010. This evolution of plants' temp share is reflected as well at the intensive as at the extensive margin, with both the temp share of plants already utilising TAW (depicted by the dashed line in Figure 1) and the share of plants using TAW (depicted by the dotted line in Figure 1) rising until 2008, dropping substantially in 2009, and recovering in 2010. A more detailed look at plants' TAW use during the Great Recession in my sample further reveals that three quarters of plants making use of TAW in either 2008 or 2009 reduced their temp share in the crisis year 2009 and that two thirds of plants utilising TAW in either 2009 or 2010 raised their temp share in the recovery year 2010. This descriptive evidence is suggestive that plants use TAW to flexibly adjust their labour force to their product market demand. I now turn to the question whether plants' use of TAW has also lead to more stable jobs for their non-TAW workers.

\section{- Figure 1 about here -}

\section{Econometric approach}

To investigate the impact of employers' TAW use on the stability of non-TAW jobs, I fit hazard rate models for the duration of non-TAW jobs including a group of dummies for the intensity of plants' TAW use as covariates. In a first specification, I model the separation rate of job $i$ at employer $j(i)$ held by worker $m(i)$ as a Cox model

$$
s_{i}\left(t \mid \mathbf{T A W}_{j(i)}(t), \mathbf{x}_{m(i)}(t), \mathbf{z}_{j(i)}(t)\right)=s_{0}(t) \exp \left(\mathbf{T A W}_{j(i)}(t)^{\prime} \boldsymbol{\alpha}+\mathbf{x}_{m(i)}(t)^{\prime} \boldsymbol{\beta}+\mathbf{z}_{j(i)}(t)^{\prime} \boldsymbol{\gamma}\right)
$$


where $s_{0}(t)$ is the baseline hazard depending on job duration $t, \mathbf{T A W}_{j(i)}(t)$ is a group of dummies indicating the share of temps among employer $j(i)$ 's workforce at job duration $t, \mathbf{x}_{m(i)}(t)$ is a vector of worker controls, $\mathbf{z}_{j(i)}(t)$ is a vector of employer controls, and $\boldsymbol{\alpha}, \boldsymbol{\beta}$, and $\boldsymbol{\gamma}$ are vectors of coefficients. My main point of interest is the coefficient vector $\boldsymbol{\alpha}$ that informs one on whether the job separation rate is lower if there are more temps among employers' workers, and thus whether non-TAW jobs are more stable if there are more temps. On the other hand, the impact of TAW may also be of opposite sign if employers substitute temps for perms, thereby lowering non-TAW workers' job stability ${ }^{6}$

Apart from increased job stability for regular workers due to TAW use within a dual labour market, a negative correlation between the non-TAW job separation rate and the temp share may also stem from good performance of employers with high plant utilisation. In this case, the employer may assign temps to meet the high demand she faces and is arguably also less likely to lay off both its TAW and non-TAW workers. To rule this channel out, I include several variables capturing employers' economic performance in $\mathbf{z}_{j(i)}(t)$ : a dummy for a good profit situation in the previous year, plants' log revenues in the previous year, two dummies indicating either a good or a bad outlook for the current year, and a set of year dummies reflecting the current state of the business cycle.

Apart from these variables, I add several other plant and worker characteristics as covariates. Worker controls $\mathbf{x}_{m(i)}(t)$ include dummies for being female, for having non-German nationality, and for being a part-time worker, two education dummies distinguishing medium-skilled workers (i.e. workers with a vocational degree) and highskilled workers (i.e. workers with an academic degree), six age dummies, and dummies for one-digit occupation. Further employer controls included in $\mathbf{z}_{j(i)}(t)$ are seven plant size dummies, the shares of female, skilled, part-time, fixed-term, and marginal workers in the plant's workforce, dummies for the existence of a collective agreement either at sector or

6 Up to now, there is little evidence on this substitution effect of TAW on regular employment, although public debate on this issue is vivid. At the aggregate level, a macro-econometric analysis by Jahn and Weber (2014b) documents a pronounced substitution effect for Germany. They find that an increase in TAW leads to a rise in overall employment and, at the same time, to a fall in non-TAW employment. It is unclear, though, whether this kind of substitution works through lower durations of existing jobs, i.e. employers laying off incumbent workers, in which case it would raise the separation rate of non-TAW jobs, or through less hires into regular jobs instead, in which case it would leave the separation rate of non-TAW jobs unaltered. 
firm level, for the existence of a works council, for being an exporter, for new production technology, for location in East Germany, and for two-digit industry. Controlling for the plant's use of fixed-term and marginal employment is particularly important in this setting because these are forms of flexible labour other than TAW employers may resort to.

Yet, TAW use may still be confounded with unobserved employer characteristics. As a case in point, poor human resource practices may, on the one hand, induce more quits and, on the other hand, force the employer to rely more heavily on TAW to cope with the resulting vacancies. This would yield a spurious positive correlation between the job separation rate and the temp share. Also, in spite of including variables capturing employers' economic situation, TAW use may still partly reflect good performance yielding a spurious negative correlation between the job separation rate and the temp share.

In a second specification, I therefore model the job separation rate as a stratified Cox model

$$
s_{i}\left(t \mid \mathbf{T A} \mathbf{W}_{j(i)}(t), \mathbf{x}_{m(i)}(t), \mathbf{z}_{j(i)}(t)\right)=s_{0 j(i)}(t) \exp \left(\mathbf{T A W} \mathbf{W}_{j(i)}(t)^{\prime} \boldsymbol{\alpha}+\mathbf{x}_{m(i)}(t)^{\prime} \boldsymbol{\beta}+\mathbf{z}_{j(i)}(t)^{\prime} \boldsymbol{\gamma}\right)
$$

with $s_{0 j(i)}(t)$ now denoting a baseline hazard that is specific to employer $j(i)$ and thus encompasses unobserved permanent employer characteristics. To estimate the stratified Cox model, I adopt the stratified partial likelihood estimator 7 This estimator allows me to sweep out the employer-specific baseline hazard without the need of identifying it and thus to estimate the covariates' coefficients $\boldsymbol{\alpha}, \boldsymbol{\beta}$, and $\boldsymbol{\gamma}$ while controlling for unobserved permanent employer characteristics in a similarly convenient way as with the within estimator in linear fixed-effects models (Ridder and Tunaln, 1999). The stratified partial likelihood estimator does so by resting identification on within-variation at the employer level and thus requires multiple jobs per employer. As my data contain information on all non-TAW jobs held by workers in plants part of the IAB Establishment Panel if jobs

\footnotetext{
$7 \quad$ It is noteworthy to stress that by allowing for an employer-specific baseline hazard the proportionality assumption inherent to the stratified Cox model needs to hold only for jobs belonging to the same employer but may very well be violated across jobs at different employers without invalidating identification (cf. Kalbfleisch and Prentice, 2002, pp. 118/119). As a consequence, the estimations relying on stratified Cox models do not suffer from the widely raised criticism against proportional hazard models.
} 
are covered by the social security system, estimation of stratified Cox models is feasible. When interpreting the estimated coefficients, though, one has to bear in mind the source of identification. For example, $\boldsymbol{\alpha}$ is now identified from variation of plants' temp share over time and thus informs one on how the separation rate of non-TAW jobs responds to plant-level changes in TAW use.

To gain additional insight into the source of changes in non-TAW job stability, a third specification splits up the overall job separation rate into the separation rates to employment and non-employment with both separation rates being modelled as (stratified) Cox models as before $]^{8}$ Unfortunately, my data do not allow me to distinguish voluntary quits from involuntary lay-offs. A crude approximation, which is in line with empirical evidence from other data sets, is that separations to employment are predominantly voluntary quits whereas most of the separations to non-employment reflect involuntary dismissals (e.g. Burda and Mertens, 2001). Applying this approximation, one would expect the effect of TAW to be more pronounced for the separation rate to nonemployment if employers' TAW use were to enhance the job stability of their non-TAW workers through less lay-offs.

\section{Results}

Fitting a Cox model for the separation rate of non-TAW jobs, the results of which are shown in the left column of Table 2, I indeed find that non-TAW jobs are more stable in plants resorting to TAW. The reduction in the job separation rate gets statistically significant once the temp share exceeds 5 per cent and peaks once the temp share is beyond 20 per cent. Reported hazard ratios indicate that, compared to plants using no TAW, the job separation rate is $16-18$ per cent lower in plants with a temp share of 5-20 per cent. In plants with a temp share of more than 20 per cent, the separation rate is even 35-40 per cent lower, a highly significant effect both from a statistical and an economic

$8 \quad$ Doing so implicitly assumes that separations to employment and non-employment are independent conditionally on observed covariates and permanent unobserved employer characteristics, for otherwise $s_{i}(t \mid \cdot)=s_{i}^{e}(t \mid \cdot)+s_{i}^{n}(t \mid \cdot)$ would not hold (with the superscript $e$ denoting employment and the superscript $n$ denoting non-employment). 
point of view $9^{9}$ With respect to the other covariates included, it suffices to say that these show no surprises and are generally in line with previous analyses for Germany such as Boockmann and Steffes (2010) or Hirsch et al. (2010).

\section{— Table 2 about here -}

One concern related to my findings is that employers' TAW use may reflect good economic performance and the reduction in job separations may thus merely mirror good plant utilisation rather than regular workers being safeguarded against job losses. To rule this channel out, the Cox model in Tabel 2 includes several controls for plant performance as well as year dummies that rinse out business cycle effects. Estimations corroborate that separations are indeed lower in well performing plants. Higher revenues, a good profit situation (both in the previous year), and a positive outlook (for the current year) are associated with lower separations (though the latter partial correlation is not statistically significant at conventional levels), whereas a negative outlook comes along with a higher separation rate. Controlling for these measures of plant performance should mitigate worries that the negative partial correlation between the job separation rate and the temp share is driven by high plant utilisation in plants with high temp shares.

Related to this, it is instructive to look at the same variables' impact in a Cox model that does not include the temp share dummies as covariates (see the left column of Table 3). If employers' use of TAW mirrored good performance and at the same time good performance increased job stability, one would expect the plant performance variables to have a more pronounced impact on job separations when dropping the temp share dummies from our model, thereby shutting down the channel of performance through plants' TAW use. Reassuringly, this does not happen. All four variables have the same

9 Given that plants' temp share exceeds 5 per cent for just 19 per cent of the observations in my sample (see Appendix Table A.1), one is tempted to wonder how relevant these impacts really are. It is important, though, to bear in mind that the temp share is varying markedly over my period of observation and that this number may thus understate employers' TAW use. Taking the time variation into account, I find that slightly more than a third of jobs are with employers whose temp share exceeds 5 per cent at least once in my observational window. Notably, half of plants using TAW at some time in the period of observation have temp shares that exceed 5 per cent at least once. I therefore argue that the estimated impacts are relevant indeed. 
quantitative impacts as before, rendering it very unlikely that the marked effect of employers' TAW use on non-TAW job stability is driven by plant performance.

\section{— Table 3 about here -}

It is also reassuring to note that the estimated hazard ratios of the temp share dummies are similar in a stratified Cox model that controls for time-invariant unobserved employer characteristics (see the right column of Table 2). As identification in the stratified Cox model relies on within-plant variation of job durations and covariates, the interpretation of the impact of the temp share is now different: I find that an increase in a plant's temp share is associated with a statistically significant drop in the job separation rate once the temp share exceeds 10 per cent, and still the drop is most pronounced once the temp share is beyond 20 per cent. As before, plant performance variables have the same impacts independent of the inclusion of the temp share dummies among the model's covariates (see the right column of Table 3). The positive impact of a rising temp share on job stability is thus unlikely to reflect improved plant performance.

As my sample is made of an inflow sample of jobs starting between 2002 and 2010 and thus of workers with quite low tenure who are less protected by German dismissal protection than high-tenure workers, one may wonder whether estimates based on such a sample exaggerate the impact of TAW on non-TAW workers' job stability. Although my data do not enable me to set up an inflow sample containing high-tenure workers, one viable way to check this conjecture is to use a stock sample of all on-going jobs with plants in my sample between 2002 and 2010. In such a stock sample, however, jobs with long durations are over-represented, yielding length-biased estimates unless adjusted properly. To do so, I follow the length bias correction proposed by Berger and Black (1998) and condition stock-sampled job durations on survival up to the beginning of the observational window. Estimated hazard ratios for some of the temp share dummies indeed show a somewhat less strong impact of plants' temp share on the non-TAW job separation rate (see Table 4). Yet, generally they are quantitatively similar to those estimated using the inflow sample (though estimates are considerably less precise as can be seen from the 
marked rise in standard errors). I thus argue that my findings based on an inflow sample of low-tenure jobs do not overstate the impact of plants' TAW use on non-TAW workers' job stability.

\section{— Table 4 about here -}

Next, I split up the overall job separation rate into the separation rate to employment and the separation rate to non-employment. If increased non-TAW job stability were to reflect that regular workers are safeguarded against involuntary job losses, one would expect the impact of TAW use on job separations to run mainly through a reduction in the separation rate to non-employment because transitions into non-employment are more likely to be involuntary. And indeed, this is what I find. As can be seen from comparing Tables 5 and 6, estimated hazard ratios do not differ much for most temp share dummies across destination states (though estimation precision is much smaller for the separation rate to employment yielding statistically insignificant hazard ratios for most temp share dummies). Consequently, the relative impact of TAW on the two separation rates is not that different. Yet, about three quarters of jobs in my sample end with a transition into non-employment, and just the remaining quarter involves a transition to employment (see Table 1). Hence, the absolute fall in the separation rate to non-employment is roughly threefold the absolute fall in the separation rate to employment when estimated hazard ratios are similar of magnitude across destination states. Increased job stability in nonTAW jobs is thus primarily driven by reduced separations to non-employment likely to mirror a drop in involuntary dismissals.

\section{— Tables 5 and 6 about here -}

\section{$5 \quad$ Issues of robustness}

To scrutinise my results further, I perform several checks of robustness: My results turn out to be highly robust to (i) changing the observational window, (ii) confining the analysis 
to jobs at plants of certain size, and (iii) restricting to certain subgroups of workers. The main results of these robustness checks are summarised in Table 7 that reports the hazard ratios of the temp share dummies estimated from my preferred specifications based on stratified Cox models ${ }^{10}$ In all checks of robustness, job stability is substantially increased if plants' temp share rises (both from a statistical and from an economic point of view) and reaches its maximum once plants' temp share exceeds 20 per cent. Furthermore, the impact of the temp share on job stability runs mainly trough reduced job separations to non-employment.

As stressed in Section 1, the current regulatory environment for TAW came into effect in 2003 when most regulations concerning the employment contract between temp workers and temp agencies ceased to have any impact. This may have affected employers' use of TAW and may thus influence my findings, although the descriptive evidence in Figure 1 does not suggest much change in both TAW incidence and prevalence between 2002 and 2003. With respect to the crisis years 2009/2010, I already noted that in 2009 Germany was hit by the Great Recession accompanied by a massive drop in TAW and a marked subsequent recovery of TAW in 2010 (see also Figure 1 which shows the same pattern for my sample). In a first group of robustness checks, I therefore repeat my analysis excluding either of these two discontinuities from the sample. Dropping the year 2002 involves restricting my analysis to an inflow sample of non-TAW jobs starting between 2003 and 2010. On the other hand, excluding the crisis years 2009/2010 means that I discard jobs starting in 2009 or 2010 and treat jobs that did not end before 2009 as rightcensored. As Table 7 makes clear, the impact of employers' TAW use on non-TAW job stability remains almost the same when excluding either the pre-reform year 2002 or the crisis years 2009/2010 (although both sample size and the precision of the estimates go down considerably). So my findings cannot stem from either of these discontinuities.

\footnotetext{
10 Note that estimated hazard ratios give the estimated relative change in the respective separation rates associated with a rise in the temp share but not the absolute change in the rate. Despite similar hazard ratios, absolute changes in the separation rate could thus differ across subsamples if there were substantial differences in the levels of the separation rate. As Appendix Table A.2 makes clear, separation rates do not differ that much across subsamples (by no more than 15 per cent). Hence, comparing hazard ratios is not misleading. What is more, within all subsamples roughly three quarters of jobs end with a transition to non-employment. So similar hazard ratios across destination states still imply that the absolute fall in the separation rate to non-employment is about threefold the absolute fall in the separation rate to employment.
} 


\section{— Table 7 about here -}

In a second group of robustness checks, I discard jobs in either plants with no more than 10 workers or plants with less than 200 workers. One reason for doing so is entirely technical: In small plants, a small change in the number of temps assigned translates into a big change in the temp share among these plants' workers. So restricting analysis to large plants may be less noisy. Another reason is that plants with ten or less workers are generally not subject to German dismissal protection and may thus have less use/need for TAW (and other forms of flexible labour). What is more, segmentation of workers into a core and a peripheral workforce seems less plausible in small plants that arguably have less division of labour at plant level. As is clear from Table 7, my results do not change when confining analysis to plants with more than 10 or at least 200 workers and are thus also robust in this respect.

In a final group of robustness checks, I restrict analysis to either full-time jobs or male workers to see whether job stability is differently affected among these subgroups of workers. Unfortunately, I do not have enough observations to perform separate analyses for part-time jobs or female workers. For both these subgroups, separate analyses would yield very imprecise estimates rendering a convincing interpretation of these impossible. As is clear from Table 7, the impact of plants' TAW use is exactly the same when excluding part-time jobs or female workers. Again, these results underscore the robustness of my findings.

\section{Conclusions}

Using an inflow sample of jobs in Germany starting in 2002-2010, this paper has investigated the impact of employers' use of TAW on regular workers' job stability. In line with dual labour market theory, I found that non-TAW job stability is larger with employers that resort to TAW.

Fitting Cox models that include a group of dummies for plants' share of temps in the workforce as covariates, my main results are (i) that the separation rate of non-TAW jobs 
is significantly lower if employers' temp share exceeds 5 per cent, (ii) that the effect on job stability peaks once the temp share exceeds 20 per cent, and (iii) that the dampening of job separations is mainly driven by reduced transitions into non-employment likely to mirror less involuntary dismissals of workers. These findings turned out to be highly robust, in particular to controlling for unobserved permanent employer characteristics by means of estimating stratified Cox models and to changes in the observational window that encompasses as well a major reform in Germany's TAW legislation in 2003 as the labour market disruption of the Great Recession in 2009/2010. What is more, further checks of robustness made clear that my results are unlikely to mirror good economic performance that at the same time boosts plants' temp share and dampens their layoffs. My findings thus suggest that regular workers are indeed safeguarded against involuntary job losses.

To the best of my knowledge, this is the first study to document at the plant rather than at some aggregate labour market level that employers' use of peripheral workers stabilises core workers' jobs. Although my findings are suggestive that employers use flexible forms of labour like TAW to buffer core workers, a deficiency with my data is that I cannot observe whether job separations were voluntary or involuntary but just, as proxy for this distinction, whether jobs ended with a transition to employment or non-employment. This adds some blurredness when it comes to interpreting my findings. It would also be instructive to know whether the effect of plants' TAW use on regular workers' job stability differs depending on the type of temps assigned, say in terms of temps' occupations or skills. In order to investigate this possible heterogeneity in the effect of TAW on job stability, one would need more information on temps and their assignments than are available in my data. Both these aspects point at promising avenues future research relying on richer data could take. 


\section{References}

Alda, H., Bender, S., and Gartner, H. (2005), 'The linked employer-employee dataset created from the IAB establishment panel and the process-produced data of the IAB (LIAB),' Schmollers Jahrbuch, 125(2):327-336.

Antoni, M. and JAHn, E.J. (2009), 'Do changes in regulation affect employment duration in temporary help agencies?' Industrial and Labor Relations Review, 62(2):226-251.

Bartelheimer, P. and Wieck, M. (2005), 'Arbeitslosigkeit und Unterbeschäftigung,' in Soziologisches Forschungsinstitut, Institut für Arbeitsmarkt- und Berufsforschung, Institut für Sozialwissenschaftliche Forschung, and Internationales Institut für empirische Sozialökonomie (eds.), 'Berichterstattung zur sozioökonomischen Entwicklung in Deutschland - Arbeit und Lebensweisen. Erster Bericht,' pp. 271-302, Wiesbaden: VS Verlag für Sozialwissenschaften.

Berger, M.C. and Black, D.A. (1998), 'The duration of medicaid spells: An analysis using flow and stock samples,' Review of Economics and Statistics, 33(4):667-675.

Boeri, T. (2011), 'Institutional reforms and dualism in European labor markets,' in O.C. Ashenfelter and D.E. Card (eds.), 'Handbook of Labor Economics,' vol. 4B, pp. 1173-1236, Amsterdam: Elsevier.

Boockmann, B. and Steffes, S. (2010), 'Workers, firms, or institutions: What determines job duration for male employees in Germany?' Industrial and Labor Relations Review, 64(1):109-127.

Burda, M.C. and Mertens, A. (2001), 'Estimating wage losses of displaced workers in Germany,' Labour Economics, 8(1):15-41.

CIETT (2012), The Agency Work Industry around the World: Economic Report 2012 Edition, Brussels: CIETT.

Ellguth, P., Kohaut, S., and Möller, I. (2014), 'The IAB Establishment Panelmethodological essentials and data quality,' Journal for Labour Market Research, 47(12):27-41.

Federal Employment Agency (2012), Arbeitsmarktberichterstattung: Der Arbeitsmarkt in Deutschland, Zeitarbeit - aktuelle Entwicklungen, Nuremberg: Federal Employment Agency.

Fitzenberger, B., Osikominu, A., and Völter, R. (2006), 'Imputation rules to improve the education variable in the IAB employment subsample,' Schmollers Jahrbuch, 126(3):405-436.

Freier, R. and Steiner, V. (2008), "Marginal employment": Stepping stone or dead end? Evaluating the German experience,' Zeitschrift für ArbeitsmarktForschung (Journal for Labour Market Research), 41(2/3):223-243.

Hirsch, B. and Mueller, S. (2012), 'The productivity effect of temporary agency work: Evidence from German panel data,' Economic Journal, 122(562):F216-F235. 
Hirsch, B., Schank, T., and Schnabel, C. (2010), 'Works councils and separations: Voice, monopoly, and insurance effects,' Industrial Relations, 49(4):566-592.

JAhn, E.J. and WeBER, E. (2014a), The effect of temporary help jobs on employment volatility, Labor and Socio-Economic Research Center, University of ErlangenNuremberg, LASER Discussion Paper No. 78.

- (2014b), 'Identifying the substitution effect of temporary agency employment,' Macroeconomic Dynamics, forthcoming.

Kalbfleisch, J.D. and Prentice, R.L. (2002), The Statistical Analysis of Failure Time Data, Hoboken, NJ: John Wiley \& Sons.

Klosterhuber, W., Heining, J., and Seth, S. (2013), Linked employer-employee data from the IAB: LIAB longitudinal model 1993-2010 (LIAB LM 9310), Institute for Employment Research, Nuremberg, FDZ-Datenreport 8/2013.

RIDDER, G. and TunAli, İ. (1999), 'Stratified partial likelihood estimation,' Journal of Econometrics, 92(2):193-232.

Saint-Paul, G. (1996), Dual Labor Markets: A Macroeconomic Perspective, Cambridge, MA: MIT Press. 


\section{Figures}

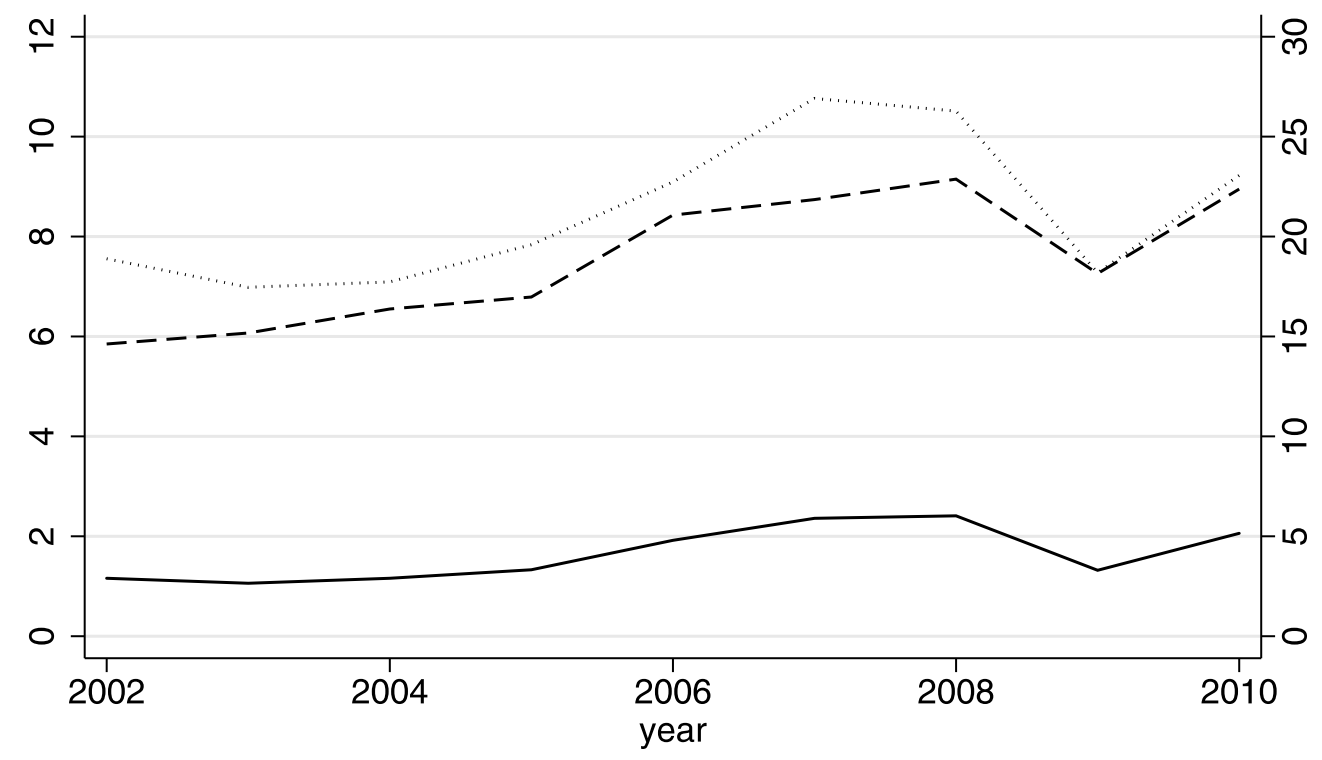

percentage of temps in plants' workforce (left scale)

- - - - - percentage of temps in user plants' workforce (left scale) percentage of plants using TAW (right scale)

Figure 1: Plants' use of temporary agency work (LIAB longitudinal model, 2002-2010). 


\section{Tables}

Table 1: Jobs and separations

\begin{tabular}{lrl}
\hline Jobs & 84,027 & \\
Workers & 75,540 & \\
Plants & 2,016 & \\
& & \\
Average job duration (days) & 826 & \\
Median job duration (days) & 551 & \\
& & \\
Separations to employment & 12,621 & $(15.0)$ \\
Separations to non-employment & 42,350 & $(50.4)$ \\
Right-censored job durations & 29,056 & $(34.6)$ \\
\hline
\end{tabular}

Notes: The data set used is the LIAB longitudinal model, 20022010. Percentages in parentheses. 
Table 2: Determinants of the overall job separation rate

\begin{tabular}{|c|c|c|c|c|}
\hline \multirow[b]{2}{*}{ Temp share $\in(0,0.05]$} & \multicolumn{2}{|c|}{ Cox model } & \multicolumn{2}{|c|}{ Stratified Cox } \\
\hline & 0.942 & $(0.046)$ & 0.984 & $(0.050)$ \\
\hline Temp share $\in(0.05,0.1]$ & $0.818^{* * *}$ & $(0.055)$ & 0.908 & $(0.073)$ \\
\hline Temp share $\in(0.1,0.15]$ & $0.842^{* *}$ & $(0.067)$ & $0.843^{* *}$ & $(0.062)$ \\
\hline Temp share $\in(0.15,0.2]$ & $0.819^{*}$ & $(0.092)$ & $0.753^{* *}$ & $(0.085)$ \\
\hline Temp share $\in(0.2,0.25]$ & $0.651^{* * *}$ & $(0.067)$ & $0.567^{* * *}$ & $(0.112)$ \\
\hline Temp share $>0.25$ & $0.603^{* * *}$ & $(0.069)$ & $0.557^{* * *}$ & $(0.073)$ \\
\hline Female & $1.129^{* * *}$ & $(0.037)$ & $1.111^{* * *}$ & $(0.032)$ \\
\hline Non-German nationality & $1.126^{* * *}$ & $(0.045)$ & $1.081^{* *}$ & $(0.035)$ \\
\hline Part-time job & 0.943 & $(0.088)$ & $0.852^{*}$ & $(0.072)$ \\
\hline Medium-skilled & $0.604^{* * *}$ & $(0.027)$ & $0.671^{* * *}$ & $(0.034)$ \\
\hline High-skilled & $0.599^{* * *}$ & $(0.034)$ & $0.640^{* * *}$ & $(0.036)$ \\
\hline Age $26-30$ years & $0.733^{* * *}$ & $(0.021)$ & $0.759^{* * *}$ & $(0.020)$ \\
\hline Age $31-35$ years & $0.672^{* * *}$ & $(0.023)$ & $0.693^{* * *}$ & $(0.022)$ \\
\hline Age $36-40$ years & $0.579^{* * *}$ & $(0.021)$ & $0.601^{* * *}$ & $(0.021)$ \\
\hline Age $41-45$ years & $0.572^{* * *}$ & $(0.023)$ & $0.587^{* * *}$ & $(0.023)$ \\
\hline Age $46-50$ years & $0.622^{* * *}$ & $(0.024)$ & $0.626^{* * *}$ & $(0.022)$ \\
\hline Age $51-55$ years & $0.927^{* *}$ & $(0.033)$ & $0.867^{* * *}$ & $(0.029)$ \\
\hline Good profit situation & $0.890^{* * *}$ & $(0.032)$ & $0.845^{* * *}$ & $(0.033)$ \\
\hline Log revenues & $0.929 * *$ & $(0.028)$ & $1.201^{* * *}$ & $(0.081)$ \\
\hline Positive outlook & 0.952 & $(0.036)$ & 0.944 & $(0.036)$ \\
\hline Negative outlook & $1.189^{* * *}$ & $(0.051)$ & $1.091^{* *}$ & $(0.042)$ \\
\hline Plant size 10-19 & 0.930 & $(0.070)$ & 0.874 & $(0.076)$ \\
\hline Plant size $20-49$ & 0.939 & $(0.084)$ & 0.898 & $(0.086)$ \\
\hline Plant size 50-99 & 0.975 & $(0.105)$ & 0.823 & $(0.101)$ \\
\hline Plant size 100-199 & 1.070 & $(0.138)$ & $0.646^{* * *}$ & $(0.094)$ \\
\hline Plant size 200-499 & 1.111 & $(0.173)$ & $0.596^{* * *}$ & $(0.113)$ \\
\hline Plant size 500-999 & 1.218 & $(0.247)$ & $0.565^{* * *}$ & $(0.124)$ \\
\hline Plant size $\geqslant 1,000$ & 1.143 & $(0.232)$ & $0.389^{* * *}$ & $(0.117)$ \\
\hline Share of female workers & 0.861 & $(0.112)$ & 0.754 & $(0.178)$ \\
\hline Share of skilled workers & $0.746^{* * *}$ & $(0.071)$ & $0.815^{*}$ & $(0.091)$ \\
\hline Share of part-time workers & 0.859 & $(0.086)$ & 1.180 & $(0.141)$ \\
\hline Share of fixed-term workers & $1.769^{* * *}$ & $(0.199)$ & 1.063 & $(0.209)$ \\
\hline Share of marginal workers & 1.163 & $(0.185)$ & 1.501 & $(0.392)$ \\
\hline Collective agreement at sector level & 0.976 & $(0.043)$ & 0.943 & $(0.044)$ \\
\hline Collective agreement at firm level & $0.862^{* * *}$ & $(0.049)$ & 0.984 & $(0.071)$ \\
\hline Works council & $0.894^{*}$ & $(0.053)$ & 0.920 & $(0.075)$ \\
\hline Exporting plant & 1.035 & $(0.067)$ & 1.080 & $(0.099)$ \\
\hline New production technology & 0.948 & $(0.044)$ & 0.925 & $(0.060)$ \\
\hline
\end{tabular}

Notes: The data set used is the LIAB longitudinal model, 2002-2010. Stratified Cox models allow for plant-specific baseline hazards. Reported numbers are hazard ratios with standard errors clustered at the plant level in parentheses. $* * * * * / *$ denotes statistical significance at the $1 / 5 / 10$ per cent level. Further covariates are dummies for one-digit occupation, two-digit industry, plant location in East Germany, and year of observation. 
Table 3: Determinants of the overall job separation rate when not controlling for plants' TAW use

\begin{tabular}{|c|c|c|}
\hline & Cox model & Stratified Cox \\
\hline Female & $1.130^{* * *}(0.037)$ & $1.111^{* * *}(0.032)$ \\
\hline Non-German nationality & $1.122^{* * *}(0.046)$ & $1.080^{* *} \quad(0.035)$ \\
\hline Part-time job & $0.943 \quad(0.088)$ & $0.853^{*} \quad(0.072)$ \\
\hline Medium-skilled & $0.605^{* * *}(0.027)$ & $0.670^{* * *}(0.034)$ \\
\hline High-skilled & $0.597^{* * *}(0.034)$ & $0.639^{* * *}(0.036)$ \\
\hline Age $26-30$ years & $0.732^{* * *}(0.021)$ & $0.760^{* * *}(0.020)$ \\
\hline Age $31-35$ years & $0.672^{* * *}(0.023)$ & $0.693^{* * *}(0.022)$ \\
\hline Age $36-40$ years & $0.579^{* * *}(0.021)$ & $0.601 * * *(0.021)$ \\
\hline Age $41-45$ years & $0.572^{* * *}(0.023)$ & $0.588^{* * *}(0.023)$ \\
\hline Age $46-50$ years & $0.623^{* * *}(0.024)$ & $0.627^{* * *}(0.022)$ \\
\hline Age $51-55$ years & $0.930^{* *} \quad(0.033)$ & $0.869^{* * *}(0.029)$ \\
\hline Good profit situation & $0.881^{* * *}(0.031)$ & $0.839^{* * *}(0.033)$ \\
\hline Log revenues & $0.922^{* * *}(0.028)$ & $1.173^{* *}(0.079)$ \\
\hline Positive outlook & $0.950 \quad(0.036)$ & $0.939 \quad(0.036)$ \\
\hline Negative outlook & $1.200^{* * *}(0.052)$ & $1.102^{* *} \quad(0.043)$ \\
\hline Plant size 10-19 & $0.936 \quad(0.070)$ & $0.883 \quad(0.075)$ \\
\hline Plant size $20-49$ & $(0.084)$ & $(0.085)$ \\
\hline Plant size $50-99$ & $(0.108)$ & $(0.102)$ \\
\hline Plant size 100-199 & $(0.141)$ & $0.656^{* * *}(0.095)$ \\
\hline Plant size $200-499$ & $(0.176)$ & $0.606^{* * *}(0.116)$ \\
\hline Plant size 500-999 & $(0.249)$ & $0.585^{* *} \quad(0.130)$ \\
\hline Plant size $\geqslant 1,000$ & $(0.238)$ & $0.407^{* * *}(0.123)$ \\
\hline Share of female workers & $0.864 \quad(0.115)$ & $0.754 \quad(0.177)$ \\
\hline Share of skilled workers & $0.767^{* * *}(0.076)$ & $0.821^{*}$ \\
\hline Share of part-time workers & $0.873 \quad(0.088)$ & $(0.143)$ \\
\hline Share of fixed-term workers & $1.806^{* * *}(0.206)$ & $(0.214)$ \\
\hline Share of marginal workers & $1.183 \quad(0.190)$ & $(0.382)$ \\
\hline Collective agreement at sector level & $0.981 \quad(0.045)$ & $(0.045)$ \\
\hline Collective agreement at firm level & $0.859^{* * *}(0.049)$ & $(0.070)$ \\
\hline Works council & $0.893^{*} \quad(0.055)$ & $(0.071)$ \\
\hline Exporting plant & $(0.067)$ & $(0.100)$ \\
\hline New production technology & $(0.043)$ & $(0.060)$ \\
\hline
\end{tabular}

Notes: The data set used is the LIAB longitudinal model, 2002-2010. Stratified Cox models allow for plant-specific baseline hazards. Reported numbers are hazard ratios with standard errors clustered at the plant level in parentheses. $* * * / * / *$ denotes statistical significance at the $1 / 5 / 10$ per cent level. Further covariates are dummies for one-digit occupation, two-digit industry, plant location in East Germany, and year of observation. 
Table 4: Determinants of the overall job separation rate in a stock sample

\begin{tabular}{|c|c|c|c|c|}
\hline & \multicolumn{2}{|c|}{ Cox model } & \multicolumn{2}{|c|}{ Stratified Cox } \\
\hline Temp share $\in(0,0.05]$ & 0.942 & $(0.058)$ & 1.020 & $(0.071)$ \\
\hline Temp share $\in(0.05,0.1]$ & $0.812^{* * *}$ & $(0.064)$ & 0.888 & $(0.071)$ \\
\hline Temp share $\in(0.1,0.15]$ & 0.912 & $(0.101)$ & 0.929 & $(0.084)$ \\
\hline Temp share $\in(0.15,0.2]$ & 0.846 & $(0.111)$ & 0.820 & $(0.105)$ \\
\hline Temp share $\in(0.2,0.25]$ & 0.747 & $(0.165)$ & $0.631^{*}$ & $(0.149)$ \\
\hline Temp share $>0.25$ & $0.607^{* * *}$ & $(0.085)$ & $0.559^{* * *}$ & $(0.082)$ \\
\hline Female & $1.172^{* * *}$ & $(0.035)$ & $1.163^{* * *}$ & $(0.032)$ \\
\hline Non-German nationality & $1.103^{* * *}$ & $(0.035)$ & $1.073^{* * *}$ & $(0.024)$ \\
\hline Part-time job & 0.917 & $(0.067)$ & $0.878^{* *}$ & $(0.049)$ \\
\hline Medium-skilled & $0.687^{* * *}$ & $(0.025)$ & $0.738^{* * *}$ & $(0.027)$ \\
\hline High-skilled & $0.740^{* * *}$ & $(0.036)$ & $0.765^{* * *}$ & $(0.029)$ \\
\hline Age $26-30$ years & $0.694^{* * *}$ & $(0.022)$ & $0.722^{* * *}$ & $(0.020)$ \\
\hline Age $31-35$ years & $0.613^{* * *}$ & $(0.022)$ & $0.640^{* * *}$ & $(0.021)$ \\
\hline Age $36-40$ years & $0.531^{* * *}$ & $(0.017)$ & $0.552^{* * *}$ & $(0.016)$ \\
\hline Age $41-45$ years & $0.504^{* * *}$ & $(0.019)$ & $0.520^{* * *}$ & $(0.018)$ \\
\hline Age $46-50$ years & $0.558^{* * *}$ & $(0.020)$ & $0.563^{* * *}$ & $(0.020)$ \\
\hline Age $51-55$ years & $1.120^{* * *}$ & $(0.043)$ & 1.029 & $(0.042)$ \\
\hline Good profit situation & $0.844^{* * *}$ & $(0.037)$ & $0.810^{* * *}$ & $(0.057)$ \\
\hline Log revenues & $0.938^{* *}$ & $(0.025)$ & $1.244^{* * *}$ & $(0.103)$ \\
\hline Positive outlook & 0.966 & $(0.046)$ & 0.984 & $(0.042)$ \\
\hline Negative outlook & $1.190^{* * *}$ & $(0.046)$ & $1.136^{* * *}$ & $(0.045)$ \\
\hline Plant size 10-19 & 0.918 & $(0.061)$ & 0.935 & $(0.081)$ \\
\hline Plant size $20-49$ & 0.931 & $(0.075)$ & 0.962 & $(0.103)$ \\
\hline Plant size $50-99$ & 0.961 & $(0.092)$ & 0.902 & $(0.122)$ \\
\hline Plant size 100-199 & 1.029 & $(0.124)$ & $0.677^{* *}$ & $(0.103)$ \\
\hline Plant size 200-499 & 1.123 & $(0.160)$ & $0.618^{* * *}$ & $(0.109)$ \\
\hline Plant size 500-999 & 1.197 & $(0.217)$ & $0.571^{* * *}$ & $(0.116)$ \\
\hline Plant size $\geqslant 1,000$ & 1.036 & $(0.209)$ & $0.294^{* * *}$ & $(0.096)$ \\
\hline Share of female workers & 0.965 & $(0.119)$ & 0.902 & $(0.217)$ \\
\hline Share of skilled workers & $0.874^{*}$ & $(0.064)$ & 0.856 & $(0.088)$ \\
\hline Share of part-time workers & $0.800^{* *}$ & $(0.084)$ & 0.933 & $(0.126)$ \\
\hline Share of fixed-term workers & $2.072^{* * *}$ & $(0.231)$ & 0.917 & $(0.194)$ \\
\hline Share of marginal workers & $1.648^{* *}$ & $(0.336)$ & 1.759 & $(0.605)$ \\
\hline Collective agreement at sector level & 0.984 & $(0.054)$ & 0.948 & $(0.054)$ \\
\hline Collective agreement at firm level & $0.821^{* * *}$ & $(0.054)$ & 1.034 & $(0.074)$ \\
\hline Works council & 0.913 & $(0.053)$ & 0.978 & $(0.080)$ \\
\hline Exporting plant & 0.969 & $(0.071)$ & 1.076 & $(0.124)$ \\
\hline New production technology & $0.881^{* *}$ & $(0.053)$ & $0.841^{*}$ & $(0.080)$ \\
\hline
\end{tabular}

Notes: The data set used is the LIAB longitudinal model, 2002-2010. Stratified Cox models allow for plant-specific baseline hazards. To correct for length bias in the estimates, I use the method from Berger and Black (1998). Reported numbers are hazard ratios with standard errors clustered at the plant level in parentheses. $* * * / * / *$ denotes statistical significance at the $1 / 5 / 10$ per cent level. Further covariates are dummies for one-digit occupation, two-digit industry, plant location in East Germany, and year of observation. 
Table 5: Determinants of the job separation rate to employment

\begin{tabular}{|c|c|c|c|c|}
\hline & \multicolumn{2}{|c|}{ Cox model } & \multicolumn{2}{|c|}{ Stratified Cox } \\
\hline Temp share $\in(0,0.05]$ & 0.887 & $(0.086)$ & 1.006 & $(0.120)$ \\
\hline Temp share $\in(0.05,0.1]$ & 0.897 & $(0.165)$ & 1.004 & $(0.241)$ \\
\hline Temp share $\in(0.1,0.15]$ & 0.892 & $(0.125)$ & 0.810 & $(0.124)$ \\
\hline Temp share $\in(0.15,0.2]$ & 0.937 & $(0.224)$ & 0.834 & $(0.166)$ \\
\hline Temp share $\in(0.2,0.25]$ & 0.754 & $(0.172)$ & 0.583 & $(0.277)$ \\
\hline Temp share $>0.25$ & $0.693^{*}$ & $(0.130)$ & $0.535^{* *}$ & $(0.142)$ \\
\hline Female & 0.958 & $(0.040)$ & $0.940^{*}$ & $(0.032)$ \\
\hline Non-German nationality & $0.892^{*}$ & $(0.060)$ & $0.901^{*}$ & $(0.054)$ \\
\hline Part-time job & $0.687^{* * *}$ & $(0.047)$ & $0.707^{* * *}$ & $(0.052)$ \\
\hline Medium-skilled & $0.850 * * *$ & $(0.050)$ & 0.960 & $(0.057)$ \\
\hline High-skilled & 1.038 & $(0.079)$ & $1.215^{* * *}$ & $(0.080)$ \\
\hline Age $26-30$ years & $0.781^{* * *}$ & $(0.035)$ & $0.803^{* * *}$ & $(0.030)$ \\
\hline Age $31-35$ years & $0.705^{* * *}$ & $(0.033)$ & $0.714^{* * *}$ & $(0.028)$ \\
\hline Age $36-40$ years & $0.636^{* * *}$ & $(0.030)$ & $0.663^{* * *}$ & $(0.028)$ \\
\hline Age $41-45$ years & $0.589^{* * *}$ & $(0.029)$ & $0.601^{* * *}$ & $(0.027)$ \\
\hline Age $46-50$ years & $0.611^{* * *}$ & $(0.034)$ & $0.594^{* * *}$ & $(0.031)$ \\
\hline Age $51-55$ years & $0.771^{* * *}$ & $(0.053)$ & $0.700^{* * *}$ & $(0.045)$ \\
\hline Good profit situation & $0.758^{* * *}$ & $(0.054)$ & $0.713^{* * *}$ & $(0.068)$ \\
\hline Log revenues & $0.875^{* *}$ & $(0.047)$ & $1.682^{* * *}$ & $(0.261)$ \\
\hline Positive outlook & 1.043 & $(0.088)$ & 0.940 & $(0.060)$ \\
\hline Negative outlook & $1.162^{* *}$ & $(0.086)$ & 1.035 & $(0.075)$ \\
\hline Plant size 10-19 & 0.967 & $(0.159)$ & $0.657^{* *}$ & $(0.135)$ \\
\hline Plant size $20-49$ & 1.293 & $(0.235)$ & 0.816 & $(0.152)$ \\
\hline Plant size $50-99$ & $1.437^{*}$ & $(0.305)$ & $0.647^{*}$ & $(0.147)$ \\
\hline Plant size 100-199 & $1.701^{* *}$ & $(0.430)$ & $0.437^{* * *}$ & $(0.110)$ \\
\hline Plant size 200-499 & $2.384^{* * *}$ & $(0.695)$ & $0.482^{* *}$ & $(0.146)$ \\
\hline Plant size 500-999 & $2.455^{* *}$ & $(0.901)$ & $0.297^{* * *}$ & $(0.108)$ \\
\hline Plant size $\geqslant 1,000$ & $2.557^{* *}$ & $(1.073)$ & $0.123^{* * *}$ & $(0.071)$ \\
\hline Share of female workers & 0.832 & $(0.193)$ & 0.818 & $(0.338)$ \\
\hline Share of skilled workers & $0.719^{*}$ & $(0.127)$ & $0.626^{* *}$ & $(0.123)$ \\
\hline Share of part-time workers & $0.684^{*}$ & $(0.135)$ & 0.967 & $(0.253)$ \\
\hline Share of fixed-term workers & 1.061 & $(0.240)$ & 0.966 & $(0.273)$ \\
\hline Share of marginal workers & 1.463 & $(0.456)$ & 1.046 & $(0.652)$ \\
\hline Collective agreement at sector level & 0.948 & $(0.112)$ & 0.957 & $(0.082)$ \\
\hline Collective agreement at firm level & $0.777^{*}$ & $(0.113)$ & 0.966 & $(0.148)$ \\
\hline Works council & $0.769^{* *}$ & $(0.080)$ & 0.869 & $(0.149)$ \\
\hline Exporting plant & 0.983 & $(0.118)$ & 1.201 & $(0.189)$ \\
\hline New production technology & 0.908 & $(0.112)$ & 0.786 & $(0.123)$ \\
\hline
\end{tabular}

Notes: The data set used is the LIAB longitudinal model, 2002-2010. Stratified Cox models allow for plant-specific baseline hazards. Reported numbers are hazard ratios with standard errors clustered at the plant level in parentheses. $* * * * * / *$ denotes statistical significance at the $1 / 5 / 10$ per cent level. Further covariates are dummies for one-digit occupation, two-digit industry, plant location in East Germany, and year of observation. 
Table 6: Determinants of the job separation rate to non-employment

\begin{tabular}{|c|c|c|c|c|}
\hline \multirow[b]{2}{*}{ Temp share $\in(0,0.05]$} & \multicolumn{2}{|c|}{ Cox model } & \multicolumn{2}{|c|}{ Stratified Cox } \\
\hline & 0.953 & $(0.046)$ & 0.972 & $(0.044)$ \\
\hline Temp share $\in(0.05,0.1]$ & $0.787^{* * *}$ & $(0.045)$ & $0.870^{* *}$ & $(0.056)$ \\
\hline Temp share $\in(0.1,0.15]$ & $0.817^{* *}$ & $(0.068)$ & $0.859^{*}$ & $(0.072)$ \\
\hline Temp share $\in(0.15,0.2]$ & $0.770^{* *}$ & $(0.091)$ & $0.708^{* * *}$ & $(0.082)$ \\
\hline Temp share $\in(0.2,0.25]$ & $0.598^{* * *}$ & $(0.063)$ & $0.527^{* * *}$ & $(0.086)$ \\
\hline Temp share $>0.25$ & $0.566^{* * *}$ & $(0.064)$ & $0.569^{* * *}$ & $(0.071)$ \\
\hline Female & $1.185^{* * *}$ & $(0.048)$ & $1.172^{* * *}$ & $(0.046)$ \\
\hline Non-German nationality & $1.196^{* * *}$ & $(0.051)$ & $1.128^{* * *}$ & $(0.037)$ \\
\hline Part-time job & 1.022 & $(0.104)$ & 0.883 & $(0.082)$ \\
\hline Medium-skilled & $0.571^{* * *}$ & $(0.026)$ & $0.633^{* * *}$ & $(0.034)$ \\
\hline High-skilled & $0.503^{* * *}$ & $(0.033)$ & $0.526^{* * *}$ & $(0.034)$ \\
\hline Age $26-30$ years & $0.719^{* * *}$ & $(0.024)$ & $0.748^{* * *}$ & $(0.024)$ \\
\hline Age $31-35$ years & $0.662^{* * *}$ & $(0.025)$ & $0.686^{* * *}$ & $(0.025)$ \\
\hline Age $36-40$ years & $0.561^{* * *}$ & $(0.022)$ & $0.580^{* * *}$ & $(0.023)$ \\
\hline Age $41-45$ years & $0.566^{* * *}$ & $(0.026)$ & $0.582^{* * *}$ & $(0.027)$ \\
\hline Age $46-50$ years & $0.625^{* * *}$ & $(0.028)$ & $0.637^{* * *}$ & $(0.027)$ \\
\hline Age $51-55$ years & 0.969 & $(0.035)$ & $0.911^{* * *}$ & $(0.032)$ \\
\hline Good profit situation & $0.931^{* *}$ & $(0.031)$ & $0.891^{* * *}$ & $(0.026)$ \\
\hline Log revenues & $0.948^{*}$ & $(0.028)$ & 1.073 & $(0.061)$ \\
\hline Positive outlook & $0.924^{* *}$ & $(0.036)$ & 0.942 & $(0.037)$ \\
\hline Negative outlook & $1.196^{* * *}$ & $(0.050)$ & $1.109^{* *}$ & $(0.045)$ \\
\hline Plant size 10-19 & 0.915 & $(0.064)$ & 0.919 & $(0.091)$ \\
\hline Plant size $20-49$ & $0.854^{*}$ & $(0.071)$ & 0.919 & $(0.099)$ \\
\hline Plant size 50-99 & 0.865 & $(0.089)$ & 0.860 & $(0.125)$ \\
\hline Plant size 100-199 & 0.928 & $(0.112)$ & $0.695^{* *}$ & $(0.128)$ \\
\hline Plant size $200-499$ & 0.884 & $(0.129)$ & $0.607^{* *}$ & $(0.142)$ \\
\hline Plant size 500-999 & 0.984 & $(0.185)$ & 0.657 & $(0.172)$ \\
\hline Plant size $\geqslant 1,000$ & 0.895 & $(0.177)$ & $0.555^{*}$ & $(0.173)$ \\
\hline Share of female workers & 0.876 & $(0.109)$ & 0.730 & $(0.186)$ \\
\hline Share of skilled workers & $0.758^{* * *}$ & $(0.076)$ & 0.865 & $(0.121)$ \\
\hline Share of part-time workers & 0.890 & $(0.094)$ & 1.120 & $(0.154)$ \\
\hline Share of fixed-term workers & $1.922^{* * *}$ & $(0.231)$ & 1.068 & $(0.234)$ \\
\hline Share of marginal workers & 1.123 & $(0.188)$ & 1.540 & $(0.435)$ \\
\hline Collective agreement at sector level & 0.985 & $(0.041)$ & 0.945 & $(0.044)$ \\
\hline Collective agreement at firm level & $0.887^{* *}$ & $(0.048)$ & 0.997 & $(0.070)$ \\
\hline Works council & 0.931 & $(0.054)$ & 0.956 & $(0.086)$ \\
\hline Exporting plant & 1.051 & $(0.065)$ & 1.021 & $(0.075)$ \\
\hline New production technology & 0.958 & $(0.041)$ & 0.986 & $(0.047)$ \\
\hline
\end{tabular}

Notes: The data set used is the LIAB longitudinal model, 2002-2010. Stratified Cox models allow for plant-specific baseline hazards. Reported numbers are hazard ratios with standard errors clustered at the plant level in parentheses. $* * * * * / *$ denotes statistical significance at the $1 / 5 / 10$ per cent level. Further covariates are dummies for one-digit occupation, two-digit industry, plant location in East Germany, and year of observation. 
Table 7: Robustness checks: stratified Cox models for the overall job separation rate and the separation rates to employment and non-employment

\begin{tabular}{|c|c|c|c|c|c|c|}
\hline & \multicolumn{2}{|c|}{ Overall } & \multicolumn{2}{|c|}{ Employment } & \multicolumn{2}{|c|}{ Non-employment } \\
\hline \multicolumn{7}{|l|}{ W/o the pre-reform year 2002} \\
\hline Temp share $\in(0,0.05]$ & 1.001 & $(0.055)$ & 1.056 & $(0.127)$ & 0.974 & $(0.052)$ \\
\hline Temp share $\in(0.05,0.1]$ & 0.928 & $(0.081)$ & 1.015 & $(0.258)$ & 0.892 & $(0.066)$ \\
\hline Temp share $\in(0.1,0.15]$ & $0.852^{* *}$ & $(0.065)$ & 0.869 & $(0.138)$ & $0.848^{*}$ & $(0.074)$ \\
\hline Temp share $\in(0.15,0.2]$ & $0.749^{* *}$ & $(0.094)$ & 0.870 & $(0.181)$ & $0.690 * * *$ & $(0.096)$ \\
\hline Temp share $\in(0.2,0.25]$ & $0.588^{* * *}$ & $(0.118)$ & 0.660 & $(0.294)$ & $0.544^{* * *}$ & $(0.099)$ \\
\hline Temp share $>0.25$ & $0.592^{* * *}$ & $(0.086)$ & $0.591^{*}$ & $(0.166)$ & $0.598^{* * *}$ & $(0.085)$ \\
\hline \multicolumn{7}{|c|}{ W/o the crisis years $2009 / 2010$} \\
\hline Temp share $\in(0,0.05]$ & 1.026 & $(0.067)$ & 1.008 & $(0.175)$ & 1.021 & $(0.058)$ \\
\hline Temp share $\in(0.05,0.1]$ & 0.906 & $(0.102)$ & 1.083 & $(0.385)$ & $0.848^{* *}$ & $(0.064)$ \\
\hline Temp share $\in(0.1,0.15]$ & 0.824 & $(0.078)$ & 0.758 & $(0.188)$ & $0.853^{*}$ & $(0.077)$ \\
\hline Temp share $\in(0.15,0.2]$ & $0.749^{* *}$ & $(0.110)$ & 0.813 & $(0.242)$ & $0.720^{* *}$ & $(0.097)$ \\
\hline Temp share $\in(0.2,0.25]$ & $0.489^{* * *}$ & $(0.095)$ & 0.499 & $(0.236)$ & $0.459^{* * *}$ & $(0.093)$ \\
\hline Temp share $>0.25$ & $0.480^{* * *}$ & $(0.07$ & $0.600^{*}$ & $(0.159)$ & $0.434^{* * *}$ & $(0.063)$ \\
\hline \multicolumn{7}{|l|}{ Plants with $>10$ workers only } \\
\hline Temp share $\in(0,0.05]$ & 0.988 & $(0.051)$ & 1.005 & $(0.121)$ & 0.977 & $(0.044)$ \\
\hline Temp share $\in(0.05,0.1]$ & 0.909 & $(0.074)$ & 0.994 & $(0.240)$ & $0.873^{* *}$ & $(0.057)$ \\
\hline Temp share $\in(0.1,0.15]$ & $0.842^{* *}$ & $(0.063)$ & 0.805 & $(0.125)$ & $0.858^{*}$ & $(0.072)$ \\
\hline Temp share $\in(0.15,0.2]$ & $0.749^{* *}$ & $(0.088)$ & 0.818 & $(0.167)$ & $0.708^{* * *}$ & $(0.084)$ \\
\hline Temp share $\in(0.2,0.25]$ & $0.562^{* * *}$ & $(0.114)$ & 0.576 & $(0.277)$ & $0.519^{* * *}$ & $(0.086)$ \\
\hline Temp share $>0.25$ & $0.550^{* * *}$ & $(0.076)$ & $0.538^{* *}$ & $(0.146)$ & $0.560^{* * *}$ & $(0.073)$ \\
\hline \multicolumn{7}{|c|}{ Plants with $\geq 200$ workers only } \\
\hline Temp share $\in(0,0.05]$ & 0.973 & $(0.066)$ & 0.957 & $(0.136)$ & 0.975 & $(0.059)$ \\
\hline Temp share $\in(0.05,0.1]$ & 0.887 & $(0.075)$ & 0.824 & $(0.131)$ & 0.904 & $(0.083)$ \\
\hline Temp share $\in(0.1,0.15]$ & 0.881 & $(0.088)$ & $0.734^{*}$ & $(0.131)$ & 0.947 & $(0.102)$ \\
\hline Temp share $\in(0.15,0.2]$ & $0.623^{* * *}$ & $(0.103)$ & 0.683 & $(0.176)$ & $0.563^{* * *}$ & $(0.084)$ \\
\hline Temp share $\in(0.2,0.25]$ & $0.467^{* * *}$ & $(0.129)$ & $0.405^{*}$ & $(0.216)$ & $0.446^{* * *}$ & $(0.102)$ \\
\hline Temp share $>0.25$ & $0.430^{* * *}$ & $(0.071)$ & $0.369^{* * *}$ & $(0.102)$ & $0.452^{* * *}$ & $(0.079)$ \\
\hline \multicolumn{7}{|l|}{ Full-time jobs only } \\
\hline Temp share $\in(0,0.05]$ & 0.979 & $(0.056)$ & 1.035 & $(0.133)$ & 0.954 & $(0.050)$ \\
\hline Temp share $\in(0.05,0.1]$ & 0.922 & $(0.079)$ & 1.066 & $(0.269)$ & $0.870^{* *}$ & $(0.059)$ \\
\hline Temp share $\in(0.1,0.15]$ & $0.828^{* *}$ & $(0.066)$ & 0.814 & $(0.130)$ & $0.834^{* *}$ & $(0.074)$ \\
\hline Temp share $\in(0.15,0.2]$ & $0.757^{* *}$ & $(0.086)$ & 0.857 & $(0.174)$ & $0.705^{* * *}$ & $(0.082)$ \\
\hline Temp share $\in(0.2,0.25]$ & $0.575^{* * *}$ & $(0.117)$ & 0.591 & $(0.286)$ & $0.531^{* * *}$ & $(0.086)$ \\
\hline Temp share $>0.25$ & $0.566^{* * *}$ & $(0.077)$ & $0.553^{* *}$ & $(0.150)$ & $0.575^{* * *}$ & $(0.073)$ \\
\hline \multicolumn{7}{|l|}{ Male workers only } \\
\hline Temp share $\in(0,0.05]$ & 0.962 & $(0.065)$ & 1.046 & $(0.156)$ & 0.930 & $(0.061)$ \\
\hline Temp share $\in(0.05,0.1]$ & 0.921 & $(0.086)$ & 1.100 & $(0.284)$ & $0.858^{*}$ & $(0.070)$ \\
\hline Temp share $\in(0.1,0.15]$ & $0.850^{*}$ & $(0.074)$ & 0.818 & $(0.152)$ & 0.863 & $(0.082)$ \\
\hline Temp share $\in(0.15,0.2]$ & $0.727^{* *}$ & $(0.094)$ & 0.887 & $(0.198)$ & $0.649^{* * *}$ & $(0.087)$ \\
\hline Temp share $\in(0.2,0.25]$ & $0.567^{* *}$ & $(0.133)$ & 0.607 & $(0.315)$ & $0.507^{* * *}$ & $(0.106)$ \\
\hline Temp share $>0.25$ & $0.561^{* * *}$ & $(0.089)$ & $0.562^{* *}$ & $(0.160)$ & $0.546^{* * *}$ & $(0.082)$ \\
\hline
\end{tabular}

Notes: The data set used is the LIAB longitudinal model, 2002-2010. Stratified Cox models allow for plant-specific baseline hazards. Reported numbers are hazard ratios with standard errors clustered at the plant level in parentheses. $* * * / * * / *$ denotes statistical significance at the $1 / 5 / 10$ per cent level. Covariates are the same as in previous tables. 


\section{Appendix}

Table A.1: Descriptive statistics

\begin{tabular}{lrr}
\hline & \multicolumn{1}{c}{ Mean } & \multicolumn{1}{c}{ St.dev. } \\
\hline Temp share & 0.029 & 0.058 \\
Temp share $\in(0,0.05]$ & 0.338 & 0.473 \\
Temp share $\in(0.05,0.1]$ & 0.092 & 0.289 \\
Temp share $\in(0.1,0.15]$ & 0.059 & 0.235 \\
Temp share $\in(0.15,0.2]$ & 0.020 & 0.139 \\
Temp share $\in(0.2,0.25]$ & 0.007 & 0.081 \\
Temp share $>0.25$ & 0.012 & 0.108 \\
Female & 0.314 & 0.464 \\
Non-German nationality & 0.071 & 0.257 \\
Part-time job & 0.121 & 0.326 \\
Low-skilled & 0.074 & 0.262 \\
Medium-skilled & 0.712 & 0.453 \\
High-skilled & 0.214 & 0.410 \\
Age & 36.337 & 9.167 \\
Good profit situation & 0.441 & 0.497 \\
Log revenues & 18.042 & 2.369 \\
Positive outlook & 0.345 & 0.475 \\
Negative outlook & 0.182 & 0.386 \\
Plant size & $2,122.842$ & $4,300.618$ \\
Share of female workers & 0.304 & 0.264 \\
Share of skilled workers & 0.803 & 0.246 \\
Share of part-time workers & 0.115 & 0.176 \\
Share of fixed-term workers & 0.081 & 0.142 \\
Share of marginal workers & 0.035 & 0.083 \\
Collective agreement at sector level & 0.525 & 0.499 \\
Collective agreement at firm level & 0.193 & 0.395 \\
Works council & 0.744 & 0.436 \\
Exporting plant & 0.564 & 0.496 \\
New production technology & 0.725 & 0.447 \\
\hline Observations & & \\
\hline
\end{tabular}

Notes: The data set used is the LIAB longitudinal model, 2002-2010. 
Table A.2: Jobs and separations

\begin{tabular}{lrrrr}
\hline & Jobs & Separations & $\begin{array}{c}\text { Separations to } \\
\text { employment }\end{array}$ & $\begin{array}{c}\text { Separations to } \\
\text { non-employment }\end{array}$ \\
\hline Full sample & 84,027 & $54,971(65.4)$ & $12,621(15.0)$ & $42,350(50.4)$ \\
W/o the pre-reform year 2003 & 74,541 & $47,590(63.8)$ & $10,947(14.7)$ & $36,643(49.2)$ \\
W/o the crisis years 2009/2010 & 71,875 & $40,798(56.8)$ & $9,705(13.5)$ & $31,093(43.3)$ \\
Plants with > 10 workers only & 80,643 & $52,252(64.8)$ & $12,072(15.0)$ & $40,180(49.8)$ \\
Plants with $\geq$ 200 workers only & 49,249 & $28,605(58.1)$ & $7,116(14.4)$ & $21.489(43.6)$ \\
Full-time jobs only & 73,481 & $48,285(65.7)$ & $11,447(15.6)$ & $36,838(50.3)$ \\
Male workers only & 55,498 & $35,745(64.4)$ & $8,414(15.2)$ & $27,331(49.2)$ \\
\hline
\end{tabular}

Notes: The data set used is the LIAB longitudinal model, 2002-2010. Percentages in parentheses. 